\title{
津波時の港内船舶の安全性向上に関する研究 STUDY ABOUT IMPROVEMENT IN SECURITY OF SHIPS AT PORT AND HARBOR AGAINST TSUNAMIS
}

\author{
岡本修 1 \\ Osamu OKAMOTO \\ 1正会員 工修 独立行政法人港湾空港技術研究所（† $239-0826$ 横須賀市長瀬3-1-1)
}

\begin{abstract}
Tsunamis caused by large-scale earthquake are considered imminent in Japan, and damage to port and harbor by tsunami is possible. Ships at port and harbor may be damaged, and ships may turn into the tsunami debris.

This paper describes the countermeasure against tsunamis at port and harbor about ships. In the past, ships were damaged by tsunamis several times. Countermeasures against tsunamis could be considered by analyzing literatures about ship damage. And the investment of countermeasure requests a large amount of money, the study of scale is needed. This paper describes also about this matter.

This study is useful for making countermeasure against tsunamis about ships, and this study shows the future works of the port authority and many researchers.
\end{abstract}

Key Words : Tsunamis, ships, countermeasures, cost-benefit analysis, earthquake probability, proper investment amount

\section{1.はじめに}

東海地震, 東南海・南海地震, 千島沖地震等, 大 規模な海溝型地震に伴う津波発生の切迫性が指摘さ れている，港湾においては，過去に，小型船舶の津 波被害が多数見られているが, 北海道南西沖地震で 1, 000 トンのバージ船が陸に乗り上げたり，スマト ラ沖地震で発電バージが $3 \mathrm{~km}$ 内陸に流されたりした という被害も報告されている。また，河田らによる と，今後の大規模津波の引き波による水位低下で大 型船舶が座礁する可能性などが指摘されている ${ }^{11}$. このため, 本研究では，小型船舶に限らず，大型船 舶を含めて, 津波時の安全性を向上させるための方 策を検討・提案するとともに, 船舶被害の防止軽減 に見合った適正なハードへの投資規模について検討 するものである。なお，船舶の安全性向上に関する 方策を体系的にとりまとめた事例はこれまでに見当 たらないのが現状である.

\section{2. 津波による船舶被害の実例と分類}

まず，本研究では，文献等調査により ${ }^{2) \sim 17) ， こ ~}$ れまでに港内の船舶が津波によってどのような被害 を受けたのかについて把握し，これらを類型化する とともに，その被災原因を分析している。ここでは その結果について示す.

\section{（1）主な船舶の津波被害}

\section{a）新潟地震}

新潟地震は1964年6月16日 13 時01分，新潟県北部 西方沖の海底深さ約 $40 \mathrm{~km}$ で発生し，マグニチュード 7.5 であった。津波は地震の約 15 分後から日本海沿 岸各地へ到達した。新潟港では, 大型船舶及び危険 物積載船はいち早く港外へ避難したが，岸壁係留中 の機帆船，漁船等は，来襲した津波に圧流され，90 隻が乗り上げ，転覆又は沈没した。新潟港において は，被害が小型船に集中していたが，これは，震源 が近く, 津波の到達が早かったため, 通信設備の乏 しい船に被害が集中したと見られており，港内残留 の大型船はいち早く係留索の増し取り等の対策を とったものと考えられている.

\section{b) 日本海中部地震}

日本海中部地震は1983年5月 26 日 11 時59分頃発生 し，マグニチュードは7.7であった．津波の第1波は, 津軽の深浦から男鹿にかけての沿岸では, 地震発生 から 7 8分後に到達し, 男鹿半島の南側沿岸では約 15〜30分後に到達した。 この津波によって, 日本海 沿岸の北海道から島根県にかけて多数の船舶に被害 が発生した。代表的なものとしては, 能代港の水面 貯木場で多数の漁船が陸に乗り上げているものがあ る. また, 漁船の転覆, 沈没, 係留綱の切断, 引き 波による防波堤への乗り上げ，引き波による水位低 下での座礁などの被害も各地で起きている。このほ か, 秋田港では，石油の揚陸中であった42,000トン 
のタンカーにローディングアームの破損, ギャング ウェイの曲損, 係留索の切断が生じたが, 錨鎖操作, 機関や舵の操縦で対処して事なきを得ている．その 際の津波高さが $1.2 \mathrm{~m}$ であったことが記録されている. c）北海道南西沖地震

北海道南西沖地震は1993年7月 12 日 22 時 17 分ごろ 発生し，マグニチュードは7.8であった。地震発生 後5分で奥尻島に津波の第1波が到達しており，船舶 の被害も多数出ている。瀬棚港では，津波により 1, 000 トンのバージ船が岸壁上に乗り上げ，起重機 船が港内の小島に乗り上げた。江差港では，押し波 時に中央埠頭側から漁船が埠頭上を乗り越え反対側 に転落し, 引き波時に逆に埠頭を乗り越えて中央埠 頭側に転落している。 このほか，引き波時に船のス クリューが海底と接触し破損した事例や，漁港内の 漁船が住宅地まで打ち上げられ, 家屋に対して強い 外力になったものと推察される事例も道内各地で あった。

\section{d）平成15年十勝沖地震}

平成 15 年の十勝沖地震は 9 月 26 日 04 時50分に発生 し，マグニチュードは8.0であった。この地震によ る津波は16分後に釧路, 17 分後に浦河で第1波が観 測されているが, 各地の最大波高はその後に観測さ れている。この津波により，46隻の漁船が転覆その 他の被害を受けている。 十勝港では, 津波によって 岸壁に漁船が打ち上げられ, イワシの好漁期に漁労 活動が停止するなどの被害を受けている。またこの 地震による津波の際, 出漁中の漁船が引き返してき たものもあったとのことである.

\section{e) 海外での事例}

2004年のインド洋大津波の際，バージ船の陸上へ の乗り上げ, 引き波による船舶の座礁等の被害が起 きている．また小型船舶の乗り上げ等も各地で見ら れている.

\section{（2）被災事例の類型化}

上で挙げた被災事例等を類型化すると, 以下のよ うになる。

(1)護岸・岸壁への乗り上げ

1993年北海道南西沖地震の奥尻港, 2003年十勝沖 地震, 2010 年チリ地震津波等で発生

(2)船舶の沈没，転覆，破損

1960年チリ地震津波により奄美大島で発生, また 1983年日本海中部地震ほか多数

(3)引き波の水位低下による座礁

2004 年インド洋大津波, 1983 年日本海中部沖地 震等での被害

(4)船舶の流失, 流出

1960 年チリ地震津波, 1946 年南海地震, 1993 年 北海道南西沖地震による被害ほか多数

(5)タンカーの防波堤への衝突による油流出

1968 年十勝沖地震による津波で, 八戸港で 2, 000 トンのタンカーが防波堤に衝突, 石油が流出

(6)係留索の切断
1983年日本海中部地震の秋田港での被害ほか

\section{(3) 被災原因の分析}

上記で類型化した被害について, 収集文献を参考 にしながら，その主要因を以下のように分析した。

まず，大型船の場合，乗り上げについては，津波 高さの大によるものが考えられる. また, 座礁につ いては, 引き波水位の大, 水深不足によるものが考 えられ, 船舶の係留索切断は, 津波高さ・流速の大, 係留索の強度不足によるものが考えられる. 防波堤 への衝突は流速の大によるものが推察される.

小型船の場合については, 各種研究の成果による と, 引き波水位も含めた津波高さを指標として被害 率の大小を議論している文献が多いが, 津波高さ・ 津波流速の大などにより, 船舶の操縦が極めて困難 となったことによるものもあると推察される.

また, 小型船の場合には, 砕波によるものや, 激 流・渦流によるものも考えられるところである.

その他の原因としては, 保険制度が休業中の収入 損失をカバーしていないことによるもの, 避難のた めの施設が不足していることによるものが考えられ る.

これらの原因を取り除くため, 各種の対策が必要 であるが，漂流物によって家屋等が破壊されている 事例については, 津波高さ・流速を抑える対策のみ では不十分と考えられることから，漂流物による被 害を抑える方向で対策を検討することが適切との考 えから対策を後述した。

\section{2010年チリ地震津波の際の対応等}

次に, 昨年2月にわが国に来襲したチリ地震津波 の際, わが国の各港湾でどのように対応したかにつ いて資料収集調查を行なった結果について示す.

多くの港湾では, 入港中の船舶に対して荷役中止 の指示を港湾管理者が発令し, 海上保安部が津波に 関する情報提供を行うとともに避難を呼びかけ，船 舶が港外避難を行なうことによって被害をまぬがれ たが，一部の港湾では対応に課題を残すケースも あった. ${ }^{18)}$ 以下にそのケースについて解説すること とする.

\section{(1) 北海道内各港, 宮城県 $\cdot$ 気仙沼}

沖合に避難した船舶が帰港寸る時間が早く, 津波 が満潮と重なって最高水位を示し, 湾内で渦が見ら れたところもあった。気仙沼海上保安署では, 帰港 時間が早かった原因を, 沖では船舶が情報を入手し にくいためではないかとしている.

\section{（2）兵庫県 $\cdot$ 福良港}

淡路島南部の福良港には，第5管区海上保安本部 が注意喚起をしたのみであった。福良港ではロープ 
で船舶を岸壁に固定する光景は見られたが，避難し たり，陸揚げしたりする船舶はほとんどなかった。 これに対し，有識者は，小規模港における津波対策 について港湾管理者主導の必要性を指摘している.

また，現在津波時に各港湾で船舶がどのような対 応を取る決まりになっているかについて文献調査等 を実施したところ，無線等による避難の呼びかけを 実施することになってはいるものの，沖合では携帯 電話による小型船舶への通信が不可能となる場合が あることが明らかになっている。 ${ }^{19)}$

\section{4. 関連研究の調査結果}

つづいて，津波時の港内船舶の安全性向上に関す る既往の研究成果を整理するとともに，これらから 見て取れる今後の課題について整理した. 以下に, その結果について示す.

\section{(1) 片田らの研究について}

陸上滞在時に津波の予想高さが $6 \mathrm{~m}$ 以上の場合は 漁船を沖に避難させないなど, 危険な状況下におけ る漁船避難を回避する避難ルールを提案し, 信号に よる指示を行なう方式とするとともに，無線設備の ない漁船に有効な情報伝達手段として「赤旗」を採 用している.これは, 北海道の落石漁港で開催した ワーキンググループの検討結果を踏まえたものであ る. 20)

\section{（2）風間らの研究について}

人命を第一に考えた小型船舶の避難に関する考え 方として, 港周辺もしくは沖合で航行している小型 船舶は, 避難海域に移動した方が早い場合には直ち に避難海域に避難すること, 沖へ避難した小型船舶 は津波警報・注意報が解除されるまでは沖で待機す ること, 港内で停泊している場合には港へ船舶を見 に行かずに船舶による港外避難は行なわないことを 提案している. ${ }^{21)}$

\section{（3）河田らの研究について}

1, 000 t以上の大型船舶について, 引き波による座 礁, 押し波による乗り上げ，津波の流れと水位の上 昇による係留策の切断についての被害評価手法を開 発したもので, これによると，3.5m以上の津波高で 船舶の乗り上げ被害, 津波高 $7.0 \mathrm{~m}$ で船舶の係留策 切断, 津波流速 $3.9 \mathrm{~m} / \mathrm{s}$ で係留策の切断が生じる可能 性が指摘されている。また, 座礁に対する安全マッ プを同時に示し，被害軽減のための情報としている。 1)

また，2003年十勝沖地震における漁民の避難行動 に関する実態調査によると, 漁船の帰港時間が漁民 ごとに異なり，洋上で情報から孤立した漁民にとっ ては，帰港の際に危険が伴うことが明らかになって
いる. また多くの漁船に数台の漁業無線機が搭載さ れているにもかかわらず, 出漁中の漁民と漁業組合 との情報伝達手段として，災害時に輻輳する可能性 が非常に高い携帯電話を漁業無線よりも頻繁に用い ていることが判明している。 ${ }^{22)}$

\section{(4) 既往の研究からみた船舶の安全性に関する課題}

これらの文献からは，以下の課題を抽出した。

- 小型船舶の航行実態や操縦性能調査等による安全 な海上避難の条件の精度向上

・正確な情報を迅速かつ適切に船舶に伝達する方法 の検討

・協議会を通じた地域における避難海域及び避難行 動のルール設定方法の検討

\section{5. 船舶の安全性向上に関する課題の整理・ 抽出}

前章までの調查結果をもとに，ここでは，津波時 の船舶の安全性向上に関する課題の整理・抽出を行 なう。

まず，大型船については，船舶の乗り上げ，引き 波による座礁, といった被害が起こりうることが考 えられる.このため,

・津波高さ, 流速の低減, 座礁の防止

・係留索の切断防止 が課題となるものと考えられる.

また小型船については，4，で挙げたものととも に,

・津波高さ，砕波，流速の低減，座礁の防止

・係留索の切断防止

・漂流物の防止

・保険制度の充実

・対策実施における県など公的主体によるリーダー シップの発揮

が課題として挙げられる。

\section{6. 船舶安全性向上に有効な対策の検討·提案}

4. 及び5.で挙げた課題に対応して, 有効であ ると考えられる対策のフレームを表-1に挙げる.

このうち, 津波高さ・流速の低減については防波 堤・ゲート整備により対応可能なものと考えている. 事実, 防波堤の整備によって津波防護効果が得られ るものとの報告もなされている。 ${ }^{23) 24)}$

また，船舶に対する情報提供手段として，無線や 津波防災ステーションの機能強化による対応策を掲 げている，将来的には，衛星を活用することにより 船舶情報の可視化を実現し, 津波情報の的確な提供 につなげることが重要と考えている.

また，現状では，商売道具である漁船が津波時に 
表-1 船舶安全性向上に資する対策のフレーム

\begin{tabular}{|c|c|c|c|}
\hline 主体 & 短期的施策 & 中期的施策 & 長期的施策 \\
\hline 国 & • B C P策定支援 & $\begin{array}{l}\text { ・防波堤かさ上げ } \\
\text { ・G P S 津波計の計画的 } \\
\text { 配備 }\end{array}$ & $\begin{array}{l}\text { - 防波堤延長・沖防波堤整備 } \\
\text { ・ゲート設置 } \\
\text { ・航路・泊地整備 } \\
\text { ・津波情報提供に関する技術 } \\
\text { 開発 }\end{array}$ \\
\hline 地方 & - B C P策定 & $\begin{array}{l}\text { ・ 小規模防波堤・航路・ } \\
\text { 泊地整備 } \\
\text { ・艇庫整備 } \\
\text { • 無線整備 } \\
\text { ・漂流物防止柵整備 } \\
\text { ・人命避難用施設整備 }\end{array}$ & $\begin{array}{l}\text { ・避難用ドック整備 } \\
\text { ・津波防災ステーションの機 } \\
\text { 能強化 } \\
\text { ・防潮堤整備 }\end{array}$ \\
\hline 民間 & $\begin{array}{l}\cdot \text { ・協議会設置 } \\
\text { ・バース会議活用 } \\
\text { ・空ドックの活用 } \\
\text { ・係留方法変更 }\end{array}$ & $\begin{array}{l}\text { ・強化係留索の開発 } \\
\text { ・保険制度の創設 } \\
\text { ・ I Tツールの開発推進 } \\
\text { ・防舷材開発 }\end{array}$ & $\begin{array}{l}\text { - 衛星による避難支援 } \\
\text { （船舶情報の可視化） }\end{array}$ \\
\hline
\end{tabular}

気になるため港へ確認しにいく漁民も多いことから， 被災後の休業保障に関する保険制度の創設も待たれ るところであると考え，民間部門の中期的課題とし て取り上げた。船舶の座礁等については, 航路・泊 地整備で対応することが挙げられる. 小型船の被害 は砕波によるものであることもいわれており，砕波 防止のためにも泊地の増深が有効であるものと考え られる。 25)

ほかにも, 小型船舶に対しては係留方法の変更が 被害軽減に対して有効であることも報告されている ほか, ${ }^{26)}$ 地元協議会によるルールづくりも必要であ ると考えられる.

船舶の陸上避難等については, 空ドックの活用, 避難用ドックの整備, 艇庫の整備による対策が有効 であるものと考えられる。

また，小規模港では，県などの港湾管理者がリー ダーシップを取り， B C P 策定といった形で対応す るのが望ましいと考えられる， B C P の策定フロー を参考までに図-1に示す。

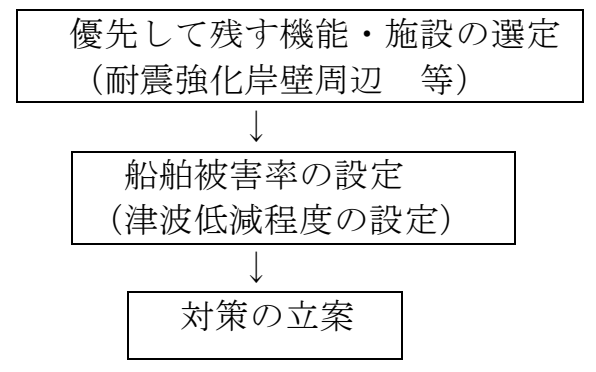

図-1Ｂ C P 策定のフロー

ここで，表-1においては，技術的支援に関するも の, 多額の投資を要するものを国の施策と位置づけ るとともに，比較的投資額の少ないもの，地域に根
ざした施策であるものを地方の施策とした．また， その他の施策を民間の施策とし, 実施の難易を加味 して, 短期的施策, 中期的施策, 長期的施策に分類 している.

\section{7. リスクマネジメントの考え方}

ここでは，船舶に関する津波対策を具体化するに 当たっての考え方として，リスクマネジメントの観 点からリスク対策を分類する. リスク対策は以下の ように分類される。 ${ }^{27)}$

\section{a)リスク保有の観点から}

すべてのリスクについて万全の対策を講じること は現実には不可能であると考え, リスクを保有し, 船舶所有者の人命被害回避に向けた対策をとる.

\section{b)リスク低減の観点から}

設備投資について, 船舶の安全性向上のため, 費 用対効果が高ければ防波堤やゲート, 漂流物防止椢 等を設置する．また B C P による意識向上などの対 策も考えられる.

\section{c)リスク回避の観点から}

リスクレベルが高く改善策が無いと判断される場 合には，リスク回避のため港湾自体を移転する.

\section{d）リスク移転の観点から}

被害規模が大きく発生確率が小さい津波に対して は，対策費用が高額となり，その投資負担に耐えら れないと判断される場合に, 新たな保険制度の創設 によりリスクの移転を図る方法で対応する.

実際に対策を実施するに当っては，これらの考え 方をそれぞれ単独で実施するわけではなく, 適宜取 捨選択しつつ実施していくことが望ましいと考えら れており，地域特性に配慮しつつ実施していくこと 
となる。

\section{8. 適正投資規模の検討}

つづいて，主にハード対策に関して，発生頻度や 確率を考慮したうえでの投資額の適正規模について, 港湾投資の費用便益分析を援用しつつ検討した結果 について示すこととする。 ${ }^{28)}$

これは, 現在, 今後含めて, いかに効率的に対策 を実施するかについての対応が求められることを意 識したものであり，7．において示したリスク対策 の考え方を具体化する際の目安となるものである.

ここで，対象となる災害を，

(1) 東海地震

(2) 東南海地震

(3) 南海地震

(4) 発生確率 $1 / 100,1 / 150,1 / 35$ の地震

と設定した。 なお, 東海地震, 東南海地震, 南海 地震の年度別発生確率については, 地震調査委員会 から発表されているものを用いている。 ${ }^{28)}$

また対象となる期間を50年とし，

$$
B=\sum_{t=t_{o}}^{T}\left\{\left(D_{w o}-D_{w}\right) \times P(t) /(1+i)^{t}\right\}
$$

ここに,

B ：防護便益（適正投資額）

$\mathrm{D}_{\text {wo }}$ : 対策未実施時の被害額

$\mathrm{D}_{\mathrm{w}}$ : 対策実施時の被害額

$\mathrm{P}(\mathrm{t}): \mathrm{t}$ 年次における対象災害の発生確率

$\mathrm{i}$ : 社会的割引率 (4\% と設定)

$\mathrm{t}_{0}$ : 供用開始年次（便宜的に0 と仮定）

$\mathrm{T}$ ：供用終了年次（50 と設定）

とし，費用対便益が 1.0 となる場合の便益を適正 投資額と考えて試算した。被害額については，小型 船の場合に津波高さと被害率の関係を参考にして算 出できる。参考に，南海地震の年度別発生確率を

図-2に示す.

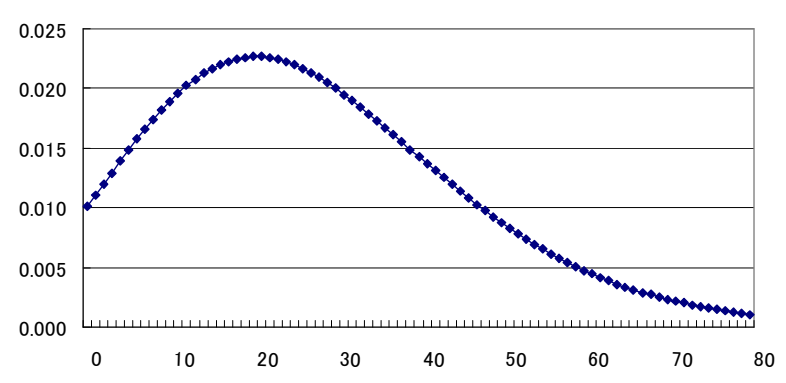

図-2 南海地震の年度別発生確率 （地震調査委員会による）

また, 東海地震, 東南海地震についても, 同様に
発生確率を考慮することにより，式(1)により低減 被害額に対する適正投資規模をそれぞれ試算した。

これらにより, 各地震時の適正投資規模（B/

(Dwo-Dw））の試算結果を示すと，以下の表-2 のようになる.

表-2 津波災害に対する適正投資規模の試算結果

\begin{tabular}{|l|l|}
\hline \multicolumn{1}{|c|}{ 地震 } & 適正投資規模 \\
\hline 東海地震 & 低減被害額の約 $62 \%$ \\
\hline 東南海地震 & 低減被害額の約 $36 \%$ \\
\hline 南海地震 & 低減被害額の約 $39 \%$ \\
\hline 確率 $1 / 35$ の地震 & 低減被害額の約 $64 \%$ \\
\hline 確率 $1 / 1000$ 地震 & 低減被害額の約 $22 \%$ \\
\hline 確率 $1 / 1500$ 地震 & 低減被害額の約 $15 \%$ \\
\hline
\end{tabular}

発生の切迫している東海地震, また発生頻度が 比較的高い確率 $1 / 35$ の地震では低減被害額の約6割 が適正投資額となるとの結果が得られ, 東南海・南 海地震では約4割との結果が得られた。

仮に，小型船舶1隻あたりの価格を3, 314千円（調 査結果による），被災隻数を 100 隻とし，南海地震 発生地域での全損被害を防止する適正投資規模を試 算すると, 現在価值割引後で約 1 億 2 千万円となる. これは小型船だまりでの防波堤延長約 $30 \mathrm{~m}$ 分に值す る.

なお，防波堤延長，沖防波堤整備等による効果に ついては, 小型船舶の被害防止以外にも, 背後地の 浸水被害低減, 台風時の被害低減等の効果があり, 整備に要する期間を勘案しても, 事実上の適正投資 規模が表-2よりも多くなりうることを申し添えてお く。また，実際に対策を立案・計画していく際には， 津波からの防護効果のみでなく, 台風や冬季風浪か らの防護効果も勘案しつつ行なっていくことが肝要 であり，表-1に示した施策をパッケージにて実施に 移していくことを意識することもあわせて必要にな るものと考えられる.

\section{9.おわりに}

過去，津波時においては，漁船をはじめとする小 型船舶の転覆, 沈没, 係留索の切断, 岸壁への乗り 上げ，引き波による船底の接触や，大型船の座礁等 の被害が各地で見られている。実際に津波が来襲し た際には，船舶を港外に避難させるだけの時間的な 余裕がなく, ハードで防護する場面も少なくないと 考えられる.

そのため, 本研究を皮切りに, 港湾で必要なハー ド対策も，ソフト対策と同様に充実させておくこと が今後かなり重要になってくるものと考え, 本稿の 執筆に至った。

昨今においても，ハード対策が無駄なものと考え られる風潮がいまだに根強く残っているが，必要な 投資を行い，災害を低減していくことは，次世代の 
ための投資でもあることを忘れてはならない.

確かに，災害の発生頻度が低いことは間違いのな いことであるが，2003年十勝沖地震のように，災害 の発生確率が $60 \%$ といわていた場合であっても実 際に発生しているということを肝に銘じるべきであ ると考える。

災害が実際に起こってから，ハード整備の不足が 何度も過去に言われてきている事実もまた見逃せな い. 今後, ハード・ソフト対策を連携させ，準備を 万全に行なうことを急がなければならない。

なお，今後の主な課題として，船舶の避難に関す る検討が残っており，津波避難時の船舶の性能を正 確に把握するとともに, 海上避難に関する条件の精 度を向上させていく必要がある.こちらについても 今後当研究所で実験・解析的に取り組んでいきたい と考えている.

最後に, 本稿が船舶の所有者, 港湾管理者, 研究 者等にとって，津波対策に向かう一つの指針となり 津波対策を進めるうえでの参考資料になることを 願ってやまない.

\section{参考文献}

1) 河田惠昭, 新名恭仁, 原田賢治, 鈴木進吾 : 津波によ る船舶被害の評価手法の提案, 土木学会海岸工学論文 集, 第 51 巻, pp. 316-320, 2004.

2) 日本海難防止協会 : 津波が予想される場合の船舶安全 確保に関する調查研究報告書（平成 15 年度），2004.

3) 渡辺偉夫：日本被害津波総覧（第 2 版）, 東京大学出 版会, 1998.

4) 川真田桂, 高岡一章, 藤井裕之, 山木滋 : 津波による 施設の被災シナリオに関する検討一船舶避難に関する 検討例一, 土木学会海洋開発論文集, 第 22 巻, pp. 553-558, 2006.

5）首藤伸夫, 佐竹健治, 松富英夫, 今村文彦, 越村俊一 編：津波の事典，朝倉書店，2007.

6) 谷本勝利, 高山知司, 村上和男, 村田繁, 鶴谷広一, 高橋重雄, 森川雅行, 吉本靖俊, 中野晋, 平石哲也 : 1983 年日本海中部地震津波の実態と二・三の考察, 港 湾技術研究所資料, No. 470, pp. 105-108, 1983.

7) 秋田県土木部港湾課 : 1983 年日本海中部地震 港湾施 設の被害と復旧, pp. 95-96, 1984.

8) 山本正昭, 中山哲嚴, 坂井淳, 三橋宏次 : 日本海中部 地震津波による漁港内の漁船被害, 土木学会海岸工学 論文集，第 32 巻, pp. 460-464， 1985.

9) 高山知司, 鈴木康正, 鶴谷広一, 高橋重雄, 後藤智明, 永井紀彦, 橋本典明, 長尾毅, 細山田得三, 下迫健一 郎, 遠藤仁彦, 浅井正 : 1993 年北海道南西沖地震津波 の特性と被害, 港湾技術研究所資料, No. 775, pp. 96128. 1994.

10) 富田孝史, 河合弘泰, 柿沼太郎: 平成 15 年十勝沖地 震津波による被害と津波の特性, 港湾空港技術研究所 資料, No. 1082, pp. 9-27, 2004.

11)平石哲也, 有川太郎, 南靖彦, 田中政典：インド洋地 震津波の被害例についてータイにおける事例を中心と して一，港湾空港技術研究所資料，No. 1106, pp. 11-18, 2005 .
12) 富田孝史, 本多和彦, 菅野高弘, 有川太郎：インド洋 津波によるスリランカ, モルディブ, インドネシアの被 害現地調查報告と数值解析, 港湾空港技術研究所資料, No. 1110, pp. 21-33, 2005.

13) 熊谷兼太郎, 小澤敬二 : スリランカにおけるインド洋 津波被害の現地調查, 国土技術政策総合研究所資料, No. 304, pp. 11, 2006.

14) 辰巳大介, 藤間功司, Subandono Diposaptono, 富田孝 史, 高橋重雄 : 2006 年ジャワ島津波の現地被害調査報 告, 港湾空港技術研究所資料, No. 1157, pp. 10-12, 2007.

15）富田孝史，有川太郎，辰巳大介，本多和彦，東野洋司， 渡辺一也：2007 年ソロモン諸島津波の現地調査報告, 港湾空港技術研究所資料, No. 1179, pp. 23-26, 2008.

16) 有川太郎, 辰巳大介, 松崎義孝, 富田孝史：2009 年 サモア諸島津波の現地調査, 港湾空港技術研究所資料, No. 1211, pp. 8, 2010.

17) 高橋重雄, 菅野高弘, 富田孝史, 有川太郎, 辰巳大介, 加島寛章, 村田進, 松岡義博, 中村友昭 : 2010 年チリ 地震・津波による港湾・海岸の被害に関する調査報告書, 港湾空港技術研究所資料, No. 1224, pp. 14-37, 2010.

18) 都司嘉宣, 大年邦雄, 中野晋, 西村裕一, 藤間功司, 今村文彦, 柿沼太郎, 中村有吾, 今井健太郎, 後藤和 久, 行谷佑一, 鈴木進吾, 城下英行, 松㟝義孝: 2010 年チリ中部地震による日本での津波被害に関する広域 現地調查, 土木学会論文集 B2 (海岸工学), Vol.66, No. 1， 1346-1350， 2010.

19) 財団法人海技資格更新協力センター：海技と知識, 2006.

20）片田敏孝，村澤直樹，高柳省一，岩佐雅教，松下圭 吾: 津波襲来時における漁船の避難対応に関する研究, 土木学会論文集 B2（海岸工学）, Vo1. B2-65, No. 1, pp. 1331-1335, 2009.

21）風間隆宏, 中村隆, 伊藤敏朗, 大塚浩二, 佐藤勝弘, 今津雄吾 : 津波による船舶被害軽減のための避難海域 に関する検討, 土木学会海岸工学論文集, 第 53 巻, pp. 1356-1360, 2006.

22) 田中亮平, 河田惠昭, 井上雅夫, 原田賢治, 高橋智 幸 : 2003 年十勝沖地震時における漁民の避難行動に関 する実態調査, 土木学会海岸工学論文集, 第 51 巻, pp. 1301-1305, 2004.

23) 明田定満, 谷野賢二, 水野雄三, 佐藤仁, 寺内啓 : 港 湾漁港施設による津波被害の低減効果について, 土木 学会海岸工学論文集, 第 41 巻, pp. 1176-1180, 1994.

24) 小田勝也, 早川哲也, 直井秀市: 港湾における防波堤 の津波対策効果に関する考察, 土木学会海岸工学論文 集, 第 52 巻, pp. 291-295, 2005.

25) 大橋太郎, 越村俊一, 今村文彦 : 津波来襲時の海上八 ザードマップ作成要件の検討, 土木学会海岸工学論文 集, 第 54 巻, pp. 1351-1355, 2007.

26) 齋藤正文, 伊藤孝, 中村雅博, 藤間功司, 鴫原良典, 三宅健一：津波による漁船等小型船舶の係留索に作用 する実用的な張力算定式の提案, 土木学会海洋開発論 文集, 第 25 巻, pp63-68, 2009.

27) 社団法人日本技術士会：技術士制度における総合技術 監理部門の技術体系（第 2 版），2004.

28) 国土交通省港湾局関係公共事業評価手法研究委員会 : 港湾整備事業の費用対効果分析マニュアル， III-9-16, 2004. 